\title{
Prisoners and the Law: Rethinking Prisoners' Rights and Implementation Challenges in Kenya's Justice System
}

\author{
Abel Bennett Holla ${ }^{1}$ \\ ${ }^{1}$ Chuka University \\ P. 0. Box 109-60400, Chuka, Kenya
}

DOI: $10.22178 /$ pos.61-3

JEL Classification: K40

Received 26.06.2020

Accepted 28.07.2020

Published online 31.08.2020

Corresponding Author:

abelholla@gmail.com

(c) 2020 The Author. This article

is licensed under a Creative Commons

Attribution 4.0 License @) (1)

\begin{abstract}
International Organizations such as the Council of Europe and the United Nations have developed several legal provisions on prisoners' rights. These liberal rules are intended to improve how various actors handle incarcerated offenders in the criminal justice system. Local legislations have similarly been developed by various countries to protect and safeguard the right of prisoners. This review will examine various international legal provisions and the local statutory requirements available under the Kenyan justice system. In particular, the requirements of the United Nations Standard Minimum Rules for the Treatment of Prisoners (UNSMR) will be examined and compared to various local legal provisions in the Penal code and the Prisons Act (CAP 90 of the Laws of Kenya). Additionally, the examination will cover some of the challenges that hinder the effective implementation of local and international rules on prisoners' rights in the Kenyan context.
\end{abstract}

Keywords: incarceration; penitence; discrimination; rehabilitation.

\section{INTRODUCTION}

An evaluation of various international statutes and local legislation on prisoners' treatment raises essential questions about the notion of rights and how they are conceptualized and executed by multiple actors in the Kenyan context. Although the historical objective of incarceration has included penitence, deterrence, containment, and rehabilitation, the application of these philosophies has been fraught with challenges. In this review paper, I examine various legal provisions that seek to protect prisoners' rights and safeguard their welfare in Kenyan prisons. The discussion aims to further stimulate interdisciplinary debate between different actors of the criminal justice system to find appropriate strategies for effectively managing offenders.

\section{RESULTS}

Following the promulgation of Kenya's Constitution in 2010, any international law in effect at the time of the enactment became part of the law library in Kenya. Similarly, as per Article 2(5), (6), of the Constitution, any treaty signed by the Republic of Kenya attained similar status [7]. As such, the provisions of the United Nations Standard Minimum Rules for the Treatment of Prisoners (UNSMR) regarding the treatment of inmates apply in Kenya. The Kenyan criminal justice system is, therefore, mandated to implement these provisions in the context of the local prison.

The UNSMR constitute the internationally recommended standard operational rules for handling inmates. The Economic and Social Council made an important decision that emphasized the Standard Minimum Rules' inherent character. It enhanced the remit of the Rules to include persons "arrested and imprisoned without charge" [4]. This inclusion meant that other victims of arbitrary arrests, who were sometimes subject to unfair and unjust treatment by criminal justice agencies, could be heard. In Kenya, the implication of this new provision was that police could no longer detain suspects indefinitely without charging them and arraigning them in court for trial.

Other international human rights instruments have been incorporated into the Kenyan constitution and various enabling legislation, which are aimed at protecting human rights. Principal among these is the Universal Declaration of $\mathrm{Hu}$ man Rights (UDHR). It is regarded as one of the 
most seminal documents ever produced in the history of human rights. Proclaimed in 1948 by the UN General Assembly, it represents the "common standard of achievements for all peoples and all nations" and provides the fundamental human rights, which are universally protected [5]. Similar to the American declaration of independence, the UDHR makes cognizance of the innate nature of human beings to be born free and have the same entitlement to dignity and benefits. As such, despite the position he would have in terms of legal liberty, a human being shall not lose their dignity and rights. Hence, the incarceration of an individual does not and should not deprive them of their dignity and rights [5]. The UDHR also compels state actors to provide a justifiable but effective remedy for violations of the provisions granted to individuals under the declaration [5]. This provision can be seen in the actual resolution of these rights in the Kenyan constitution and elaborate sanctions through the Penal Code and other enabling legislation for violations of the same [9]. Central to the right of prisoners, the UDHR provides that no person shall be subjected to, among others, arbitrary arrest and detention [5]. This requirement is further entrenched through the provisions of the Kenyan constitution in Articles 29, $48,49,50$, and 51[7].

Fundamental to the full protection and enjoyment of human rights is the recognition of everyone as a person. Holding any person under slavery and all forms of servitude are prohibited since these acts amount to discrimination [5]. Consequently, discrimination should not be used to deny people their rights as envisaged in the UDHR. Moreover, people should not be discriminated against based on their status. Without this recognition as a person, the rights accruing to an inmate would not be meaningful, and the enjoyment of rights such as those of habeas corpus and the entire magnitude contemplated in Art 25 of the Kenyan [7] would not be attainable. The holding of a person in incarceration does not mean that they are to be held as slaves or subjected to conditions of slavery, even when they are serving a life sentence without the possibility of parole [5]. Consequently, no inmate shall be exposed or be subject to torture or punishment that is regarded as cruel, inhuman, or degrading [5]. In Kenya, this led to the abolition of the corporal penalty in prisons.

Equally important is the requirement that all persons shall be regarded, and treated, as equal, and without discrimination, in regards to protection by the law [3]. Equal treatment includes protection against incitement to discrimination. Such protection is essential as it ensures that inmates are covered under law, and their discrimination is banned, and any attempt at inciting others against the prison population is thwarted. It also provides an avenue where aid to inmates can be realized in various forms and from multiple stakeholders. In the same breath, the life, liberty, and security of a person are not only protected by the state actors but are behooved to ensure equal protection. It is from this premise that calls for the removals of the death penalty and its execution have their origin [3]. The death penalty contradicts the fundamental right to life and is the ultimate denial of liberty. Borrowing heavily from the UDHR, the African Charter for Human and Peoples Rights (ACHPR) provides similar rights to all persons and people with the same provisions for inmates and incarcerated persons [1].

Moreover, in express terms, ACHPR recognizes the inherent dignity of a human being and further prohibits punishment and treatment that is inhuman, cruel, or in any manner, degrading [1]. Additionally, arbitrary deprivation of liberty or freedom is not permitted. Police officers are required to adhere to the law when arresting and holding in custody all suspects.

In addition to not being subjected to arbitrary arrests, a person is entitled to a fair and public hearing during the process of prosecution of criminal charges leveled against them [5]. Consequently, all persons charged with criminal offenses under the laws of Kenya are guaranteed a fair and open judicial process. This right is provided for under Articles 48, 49, 50, and 51 of the Constitution of Kenya [7].

Though it would seem outside the purview of inmates' rights, the right to privacy or protection against attacks to their honor and reputation is still valid, and such should be held sacrosanct. Consequently, under the Kenyan system of rights accruing to inmates, their privacy is safeguarded, and any contact with them requires written permission from the Commissioner- General of Prisons.

Although the international and local legislation on offenders' rights seeks to safeguard certain basic human entitlements of prisoners, they are also intended to legitimize imprisonment as a social sanction. Therefore, the Standard Minimum Rule application may not necessarily conform to the notion of human rights as advocated by various human rights conventions. For instance, the right to liberty, which is recognized in the Universal 
Declaration of Human Rights, is not absolute; instead, it is interpreted in the context of other values, which might overrule or outweigh it. Public order can be considered as one such value [2]. Similarly, the right to freely participate in a community's cultural life and the right to freedom of thought, conscience, and religion, which are provided for by UDHR, need to be interpreted in light of the overarching values that may outweigh or overrule them. Incarceration places in abeyance some of an individual's fundamental rights. Article 51(1) of Kenya's Constitution reiterates that an accused person retains all the fundamental rights and freedoms save for those that would be incompatible with their incarceration [7]. For instance, prison authorities may suspend the right to custody of some personal property. An inmate shall be guaranteed the safe custody of money, clothing, and other (personal) effects, which as per prison rules, he/she is not allowed to retain. The safe custody of property is contingent upon declaration of such articles during their admission. Such items shall be returned to a prisoner upon discharge from the prison (rule 67) [6]. As outlined earlier, a person is not deprived of their fundamental rights by being incarcerated. Consequently, a prisoner's right to own property, which is guaranteed by Article 40 of the Constitution [7], is further protected by having their property registered, and even by ensuring that upon transfer to another prison facility, a record of their possession is made and forwarded to the receiving prison.

In line with the provisions of the UDHR regarding labor rights, although inmates do not enjoy the full breadth of the labor laws, their engagement in work during their incarceration is protected [5]. Their involvement in labor is subject to favorable working conditions, as their incarceration would allow. Moreover, their right to rest and leisure is not limited by incarceration. Although these rights are guaranteed to all workers, inmates are given particular consideration because they are incarcerated and are involved in forced labor.

The protection of an individual's desire for education, which includes technical and professional training, is another important provision for inmates [5]. Prisoners in Kenya are encouraged to continue with their knowledge and use appropriate facilities provided to excel in education. Many vocational training centers and educational institutions have been established within prisons as part of rehabilitation efforts and to follow the legal provisions on education for inmates.
The African Union developed the Ouagadougou Declaration and Plan of Action on Accelerating Prisons and Penal Reforms in Africa. The declaration aims to reduce the prison population, encourage the adoption of best practices in penal management, and promote the reintegration of offenders into society. It also seeks to ensure that the rule of law is applied in prison administration, makes African prisons increasingly self-sufficient, promotes an African charter that will be concerned with prisoners' rights; and, ensure that the United Nations Charter on the fundamental rights of prisoners is enshrined in the African penal management circles [3].

Principal among the recommended practices is the requirement that untried prisoners should be kept separate from those convicted (rule 11) [8]. This requirement has been incorporated in the Kenyan constitution under Article. 49(1)(e) and Art. 50(2)(a) [7]. Further to this, the Kenyan scenario is that all inmates continuing with their (criminal) cases shall be remanded at a separate facility from inmates, e.g., Nairobi Remand \& Allocation Maximum Security Prison. If this is not practically possible, the quarters housing the remand inmates shall be separate and distinct from those housing convicted inmates e.g., Kamiti Maximum Prison.

In keeping in line with ensuring the comfort and refrain from occasioning physical harm, UNSMR recommends the removal of restraints when appearing before judicial or administrative authority (rule 47) [6]. Though lacking a constitutional equivalent, it has been incorporated into the judiciary practice as accused persons are generally not handcuffed. This, however, has its exceptions: if in the opinion of the police or prison security, the inmate presents the risk of escape from lawful custody, he shall be handcuffed. This use of instruments of restraint is only as per need, and such usually are removed when the risk is no longer present (rule 48) [6]. An equal corollary to this is that the use of instruments of restraint on women during labor, childbirth, and immediately after birth (rule 48) [6] should not be practiced. As explained above, though lacking in constitutional or legislative provisions, women are generally not handcuffed in Kenya; unless the circumstances demand it. However, handcuffing women is not practiced when they're seeking medical attention or are in the conditions outlined in the above rule of the UNSMR.

Having been incarcerated and subject to the prison rules, especially those guiding the keeping 
of personal property, UNSMR mandates that access to and keeping in possession of documents related to legal proceedings shall not be subjected to rules of contraband management (control 53) [6]. As such, a prisoner's material on which he depends upon his defense, shall not be subject to the usual restrictions accruing to personal property in light of contraband management. This provision is evident in all the remand prisons where a prisoner's property concerning his defense in court, though subject to searches, is never confiscated as contraband.

It is expected that an inmate shall have on admission, information on applicable rules and regulations of the prison, the rights accruing to the inmate during the period of incarceration, and the obligations, which he will be expected to deliver. This information shall include applicable disciplinary sanctions, which he shall be subjected to in case of the violation of the said rules (rule 54) [6]. These rules shall be posted in (a) commonly used language(s), and a prominent display in common areas of the prison (control 55) [6].

Communication is an imperative requirement that is supported in various legal provisions. Even when offenders are incarcerated, communication with their families and relatives remain a key pillar of the offenders' life. Hence, UNSMR recommends that contact with family and friends be allowed under necessary supervision and at regular intervals. This communication shall include written correspondence and where possible, electronic and digital (rule 58) [6]. Within the Prisons Act (Cap 90 of the Laws of Kenya), there is an elaborate means by which physical visits and receipt and sending of postal mail by an inmate are spelled out. However, the subject matter of this discourse being inmates who are continuing with their (criminal) cases, they are not bound by the provisions of the Act, and their means of communication with the outside world is more relaxed; they can receive an unlimited number of visitors and mail. The UNSMR further protects communication with legal advisors or legal aid providers. Such communication shall be availed and shall be without delay, interception, or censorship. Full confidentiality of the correspondence shall be maintained (rule 61) [6]. In the localization of this requirement, the Constitution of Kenya in Article 49 (1)(c) \& 50(2)(g) provides for unhindered access to an advocate by an accused person [7]. Further, law assists in the criminal case of an accused person as explicated in Article 50 (7) [7]. Further to these, tradition and standard law provisions as to the practice of law by advocates guarantee the confidentiality of the client-advocate relationship to cement this constitutional provision also. Additionally, an inmate is guaranteed communication with their diplomatic and consular representatives in case they are foreign inmates. As noted earlier, international treaties that have been ratified by Kenya and other international laws are binding on the republic. As such, diplomatic agents who intend to visit their nationals held in custody are accorded that right without hindrance. As a result, inmates who are stateless or who claim refugee status shall be accorded the audience with the international authorities tasked with their protection (rule 62) [6].

A person who is incarcerated shall have access to religion, religious practices, and spiritual literature, which shall not be unreasonably denied, where possible inmates shall have access to a representative of their particular religion (rules 65, 66) [6]. This provision is further entrenched in the Constitution vide Article. 32 [7]. By practice, the prisons in Kenya do not deny religious observance to any group of adherents provided it is within the reasonable method. It does not pose a threat to security.

During removal to the courts, the inmate shall be exposed to as little as possible of public view with proper safeguards against insult, curiosity, and any publicity. Transport shall have adequate ventilation and light, and unnecessary physical hardship shall be avoided. The expenses of such transportation shall be borne by the prison authorities (rule 73) [6]. A prisoner's need for medication, court attendance, or another movement outside the place of incarceration shall be done in a manner that not only prevents their escape but one that protects and enhances their (human) dignity.

The Prison open-door policy, which was introduced as part of reforms in the Kenya Prisons Service, saw major improvements in the transportation of inmates. The improved transportation conformed to the requirements of Section 116 of the Penal Code, which acknowledges that prisoners have a right to take part in their criminal cases in court [9]. The state is required to ensure accused persons in prisons' remand custody are arraigned in court during their hearings [6]. Therefore, the transportation of prisoners to ensure they participate in their hearing is an important component of a fair trial process and an essential right of an incarcerated suspect.

As a rule, there are frequent visits to prisons by various stakeholders, all of which are aimed at 
looking into the inmates' welfare. Internal and external inspectors shall have access to the prison and inmates as per the term of their appointment. No hindrance shall be occasioned to the inspectors during the realization of their duties. The scope of their visits shall include but are not limited to, ensure adherence to existing laws, regulations, policies, and procedures (rule 83) [6]. They have the authority to access a prison's database on inmates, which includes the prison's records and condition on detention, the choice on the prison to visit, which inmates to interview, and conducting the interviews privately with both inmates and staff in the course of such visit. Moreover, the prison's authorities cannot hinder the impromptu nature of such a visit (rule 84) [6]. Further to this, there exists the office of the visiting justice, which is tasked with impromptu visits to prisons to address the issues outlined in rule 83 of UNSMR.

Inmates who are continuing with their (criminal) cases shall be presumed innocent until proven guilty and treated as such (rule 111). The 'innocent until proven guilty' principle runs central to the human rights creed. The unambiguous provision of the right to be presumed innocent until proven guilty as par Article. 49 and 50 of the Kenyan Constitution have seen a change in the way inmates are treated [7]. Consequently, the presumption of innocence principle requires that inmates who are still going on with their trials be held separate from convicted inmates. This provision goes further and incorporates children undergoing the criminal trial process. Such children are kept separate from adults in an independent institution as provided by The United Nations Standard Minimum Rules for the Treatment of Prisoners in rule 112 and Article 53(1) (f) of the Constitution [7]. Moreover, the Children Act provides for special courts for children (sec 73), stipulates a range of guarantees to a child in conflict with the law (sec. 186), specify the language to be used during a child's trial (sec 189), and proposes the restrictions on the punishment of a child upon conviction (sec 190) as well as the methods of dealing with child offenders [8]. In Kenya, children are contained in youth corrective training centers for the duration of their trial process. These are facilities are geared towards the rehabilitation of youthful offenders for a short three-term period by instilling in them discipline and fundamental life skills. For the period of the case, young offenders are held with their age-mates to avoid contamination with adult criminal offenders. Youth corrective training centers in Kenya have different and distinct establishments for boys and girls.

All basic needs and amenities accruing to a convicted inmate shall ensue in favor of one who is not condemned. Hence, food, shelter, health, and other rights accruing to a convicted inmate shall be provided mutatis mutandis to an inmate continuing with the trial (rule 114) [6]. The practice in Kenyan prisons follows closely this requirement, as there is a very slight distinction between the convicted and non-convicted inmates, mainly induced to make prison facilities and the offender population more manageable. Inmates continuing with their trial shall be permitted to wear their clothing and shall be tasked with ensuring that it is clean and suitable for use at their expense. In cases where the inmate is provided with a uniform, it shall be distinct from that supplied to convicted inmates (rule 115) [6]. The practice in Kenyan prisons is that only suspects accused of committing capital offenses, such as murder and robbery with violence, are mandated to wear a uniform. This uniform is different from that of convicted inmates, usually grey as opposed to the one donned by sentenced inmates, which is black and white striped.

Offenders who are serving their terms in prisons can be allowed to acquire books and other reading or writing materials, including newspapers at their expense. Such provisions shall be based on the interests of the administration of justice, security of the prison, and general good order of the institution (rule 117) [6]. This is in keeping in line with the development of literacy skills and an attempt to maintain as close a lifestyle as that found in a healthy society.

The centrality of legal advice to the criminal justice system in Kenya is such that it has constitutional protection. Offenders shall not be denied legal advice or legal aid through paralegals and wherein the interests of justice it is so required, such information shall be without payment (pauper briefs) (rule 119) [6]. In the criminal justice system in Kenya, there exist pauper briefs. This brief is where a court, due to the sensitivity of a matter and the financial incapacity of the accused, appoints from among the advocates in its reach, one who will handle a specific case until the logical conclusion of the matter according to Article. $50(2)(h)$ [7]. Among the cases that draw a mandatory pauper brief appointment are ones where the accused is charged with murder. However, there is increased pressure to include robbery with violence suspects in the same manner as the crime 
also draws a heavy penalty as murder. As a result of the centrality of legal advice to the Kenyan criminal justice system, an advocate's obligation to visit his/her client, who is incarcerated in remand prison, is respected by prison authorities and the advocate is given the necessary support. The relevant prison authorities facilitate such visits, and the appointments are treated with the confidentiality they deserve. The meetings take place in a secluded area or one that is generally known to host such meetings and prison officers are not required to be within earshot of the conversation. If an inmate decides to prepare their defense personally, they shall be provided with writing materials to prepare such documents. Correspondence with a legal advisor or legal aid provider shall fall under this ambit and hence shall be regarded as privileged communication (rule 120) [6]. This rule has been emphasized in the constitution in Article 50(2)(c), (g), (h), (j), and 50(5) [7].

Other than the constitution and other enabling legislation, a prisoner's right to access the criminal justice system is also supported through the mandate and core functions of the Kenya Prisons Service. In its mandate of facilitating the administration of justice by producing offenders to court, the Kenya Prisons Service is tasked with ensuring the timely and effective transportation of inmates for their court dates. This extends even for those inmates who have several cases in different parts of the country; transfers to a prison near to the court are arranged so that the inmate can have easier access to the courts. In addition to this, coordination between the judiciary and the Kenya Prisons Service has seen the setting up of periodic court sessions within the prison precincts. These are typically used to dispense with matters of mentions, the reduction of bond and bail terms, allocation of a new (favorable) court date, among other pertinent, but minor issues.

The mandate and core values of the Kenya Prisons Service have also seen paralegals' inclusion into the prisoner support system. This rule has seen prison staff members selected and trained to render support to the paralegal personnel. Additionally, other stakeholders are invited to offer pro bono legal aid to needy inmates.

As is familiar with every area, challenges exist in the delivery of access to the criminal justice system. Some of these include access to legal counsel and aid, congestion in prisons, recidivism, apathy, and stigma towards released inmates, the backlog of cases in the judiciary, among others. Access to legal counsel and aid remains a crucial concern in Kenya. Due to the prohibitive costs involved in acquiring legal counsel, some sections of society find themselves unable to get it. On the other hand, due to a lack of qualified legal aid providers, access to rudimentary legal aid is hampered. Congestion in prisons also provides a challenge, especially in the provision of basic amenities and even transport and transfers for court sessions. Due to the limited financial resources available, some activities are either postponed or provided at a slightly lesser degree. Recidivism is another challenge in the quest to provide access to the criminal justice system. Recidivism is the return to criminality by a person who has undergone rehabilitation and reformative training within the prison setup. Recidivism tends to breed apathy and stigma towards offenders as there is a general mistrust for convicted persons, which is worsened by some individuals returning to inappropriate social vices. Concomitant to recidivism is the innate apathy and stigma towards released inmates in society. Such indifference hampers a person's access to criminal justice as an affront to his human rights, which is called just deserts due to that person's previous crimes. The current backlog of cases in the judiciary that is being experienced also hampers the efficacy of the criminal justice system. Since resources are never infinite, the much is available, be it financial or human support, spread thin among the many needful cases.

\section{CONCLUSION}

From the discussion, it can be surmised that the criminal justice system entails a mesh of various players and stakeholders, distinct in their makeup but delivering on a nearly similar mandate. In looking at the criminal justice system in light of prisoners' rights, it will be discerned that the legal landscape is akin to a relay: there is a constant flow of responsibilities from one legal instrument to another, and from the international to local context. This process of managing responsibilities by multiple jurisdictions and institutions helps in realizing the collective mandate of administering justice. 


\section{REFERENCES}

1. Organization of African Unity. (1981). African Charter on Human and People's Rights. Retrieved July 1, 2020, from https://treaties.un.org/doc/Publication/UNTS/Volume\%201520/volume-1520-I26363-English.pdf

2. Kraiem, R. (1978). Prisoners' Rights and the Standard Minimum Rules for the Treatment of Offenders. International Journal of Offender Therapy and Comparative Criminology, 22(2), 156-163. doi: https://doi.org/10.1177/0306624X7802200208

3. African Commission on Human and Peoples' Rights. (1996). Ouagadougou Declaration and Plan of Action on Accelerating Prisons and Penal Reforms in Africa. Retrieved from https://www.achpr.org/legalinstruments/detail?id=42

4. United Nations. (n. d.). ECOSOC Resolutions. Retrieved from https://www.un.org/ecosoc/en/documents/resolutions

5. United Nations. (1948). Universal Declaration of Human Rights. Retrieved July 1, 2020, from https://www.ohchr.org/EN/UDHR/Documents/UDHR_Translations/eng.pdf

6. UNODC. (2015). The United Nations Standard Minimum Rules for the Treatment of Prisoners. Retrieved from https://www.unodc.org/documents/justice-and-prisonreform/Nelson_Mandela_Rules-E-ebook.pdf

7. Laws of Kenya. (2010). Constitution of Kenya. Retrieved July 1, 2020, from http://kenyalaw.org:8181/exist/kenyalex/actview.xql?actid=Const2010

8. Laws of Kenya. (2012). Children Act. Retrieved July 1, 2020, from http://kenyalaw.org/kl/filead-

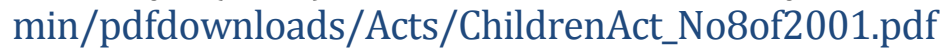

9. Laws of Kenya. (2012). Penal Code. Retrieved July 1, 2020, from https://www.ilo.org/dyn/natlex/docs/ELECTRONIC/28595/115477/F-857725769/KEN28595.pdf 